\title{
THE USE OF SPATIAL DATA FOR SEGMENTATION OF THE POSTAL SERVICE MARKET
}

\section{Dejan Marković1 ${ }^{1}$ Biljana Grgurović ${ }^{2}$, Slavica Štrbac $^{3}$}

\author{
${ }^{1}$ Faculty of Traffic and Transport Engineering, University of Belgrade, Serbia \\ ${ }^{2,3}$ Higher Education School of Professional Studies for Information and \\ Communication Technologies in Belgrade, Serbia \\ E-mails: ${ }^{1}$ mdejan@sf.bg.ac.rs; ${ }^{2}$ biljana.grgurovic@ict.edu.rs (corresponding author); \\ ${ }^{3}$ slavica.strbac@ict.edu.rs
}

Received 20 July 2009; accepted 3 January 2011

\begin{abstract}
Modern trends in the field of postal traffic imply the existence of a large number of providers who distribute these services. A trend of this kind sets highly rigorous requirements regarding structure and quality of the services. On the other hand, the users are a heterogenous group with specific characteristics, which significantly complicates the process of segmentation, choice of a target market and formulating of an adequate marketing strategy. Application of some standard methods of demographic and psychographic segmentation, in the opinion of the authors of this paper, results in very general grouping most often based on assumptions. The aim is to point out the significance of spatial data and how the results obtained by application of a geographic information system (GIS) can be used in the case of segmentation of the postal service market.
\end{abstract}

Keywords: postal traffic, market, segmentation, users, postal services, spatial data, geographic information system (GIS).

Reference to this paper should be made as follows: Marković, D.; Grgurović, B.; Štrbac, S. 2011. The use of spatial data for segmentation of the postal service market, Technological and Economic Development of Economy 17(1): 87-100.

JEL Classifications: L87, L19, M31.

\section{Introduction}

The postal services market can be defined as a complex of relationships, with the possibility of providing services for internal and international traffic which is formed between offer and demand of these services, for the purpose of large number of sale channels (Grgurović, Marković 2005). Rapid development of economy and society on the whole demands a flexible system which could meet the recently occured requirements. The hints of the market 
research are connected to the postal system reform and application of market orientation, to market liberalization and occurance of competition thereon. For all these reasons postal organisations are taking demands of the market, i.e. needs and wishes of their customers expressed in the form of demand, as the basis for commerce and forming business policy over recent years. It is necessary to make a market analysis in order to perceive and estimate basic elements (individuals, organisations and institutions) and factors (economic, sociological, technological etc.) that have impact on the market occurances. It should, primarily, provide the information necessary for proper conduction of business policy of a company (Marković, Grgurović 2006).

A complex market analysis relies on market segmentation. Thus the information necessary for identification and adequate servicing of the most attractive user groups are provided, all with the aim of expanding the range of business and company incomes. McDonald and Dunbar (2004) suggest that, no matter that a perfect way of market segmentation is not known to exist in practice, which significantly complicates the process of positioning of a company and defining its marketing strategy, some basic variables can still be defined.

On a precisely made map of the entire market which is narrowing from total further on, through different levels of elimination and acceptance, it is possible to get a picture of a potential market for a company which provides services from the field of postal sector. The extent of this market could be enlarged by changing the existent and/or introduction of some entirely new services which could be interesting for the customers (Grgurović, Štrbac 2007).

The definition of a market must be based on the sum of all services satisfying the same need (McDonald, Dunbar 2004). Since services are a variable category, appearing and disappearing according to the needs of the market, one should keep in mind the fact that some new services, which are to appear, could satisfy certain needs even better. The adequate definition of the basic categories being offered within the postal system (Lijn et al. 2005) is a precondition for further successful implementation of the segmentation process (Fig. 1).

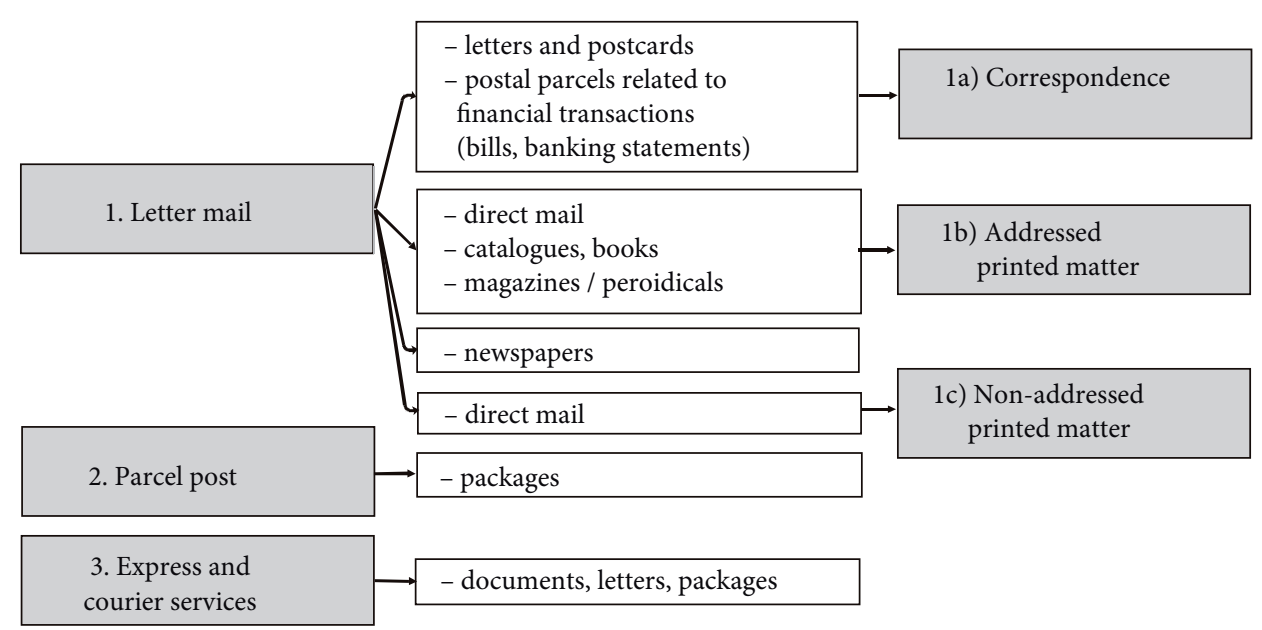

Fig. 1. Basic categories of services within the postal system 
The existing services satisfy certain needs of the customers. They can generally be described as follows: there is an adequate price range; a choice of adequate transmission rate is possible; an adequate level of safety can be obtained due to the fact that a user is free to secure the content of a parcel by defining its value; due to a large number of postal network units for service delivery, their organisational parts, postal network resources dislocated throughout the entire territory of a country and courier service, an adequate availability and simplicity of service is obtained, i.e. the possibility of choosing time and place for realization of the service; the range of the allowed weight of parcels is big enough; there is a great variety of the allowed contents of parcels; by using numerous special and additional services it is possible to reach an extremely great number of various combinations which can satisfy diverse needs of the increasingly demanding customers (Grgurović, Štrbac 2008).

A public postal operator is, by the rule, obliged to provide a group of reserved postal services on the entire territory of a country. These services are guaranteed to a postal operator by the state as an exclusive right within the scope of a ceratin limit regarding weight and price (Directive 97/67/EC). In the case of the Republic of Serbia it means that the Public Enterprise of PTT Communications "Serbia" has the monopoly in the area of letter mail, court letters, letters by legal and offense procedure and in passenger traffic (Narodna skupština Republike Srbije 2005). However, in the part relating to universal unreserved services and commercial services (parcel post, express and courier services), limited competition on one side, and unlimited competition on the other are growing stronger and more obvious (Cuadra, Ronderos 2004). Parcel post is the one that contains material over the weight of $2 \mathrm{~kg}$ and not beyond $31.5 \mathrm{~kg}$. In practice, parcels whose weight or dimensions are greater than allowed are usually taken into consideration apart from the postal sector. They are a separate, differently defined group. Express and courier services are the kind of service which set the standards in the area of parcel monitoring and processing (Ascher 2002). The battle for new additional values - door-to-door transport and delivery on the following day or any time defined, represents the core of express industry today.

According to the conditions on the market, it is in the best interest of the Public Enterprise of PTT Communications "Serbia" that, instead of wasting their energy trying to place their entire assortment, they identify one or more attractive submarkets for some sorts and categories of services, which will correspond to their potentials (JP PTT saobraćaja "Srbija" 2008). The standard means of segmantation, usually based on presumptions, didn 't show any results. Number of providers offering the same service or a service that satisfies the same kind of need is constantly increasing. All these companies are quite close concerning prices, deadlines and safety of transport, therefore creating some sort of differential advantage must be emphasized (Berry et al. 2006).

It is well known that a geographic information system (GIS) is a computer system created for collecting, processing, controlling, analyzing, displaying and maintenance of spatially oriented data. The term GIS is generally related to urban planning, building sites, various and numerous distributive systems and networks, ecology etc. The primary aim of this paper is to point out the possibility of using and significance of spatial data in business activity of providers dealing with transport of postal parcels and providing various services from this area, as well as to set the basis and frame for using and future application of GIS in market segmentation area. 


\section{Geographic information system (GIS)}

GIS was designed to allow digital coverage and editing, storage and re-organization, modeling and analysis, as well as alphanumeric and graphic display of spatial data. Due to the fact that this technology is designed for spatial oriented data management, it is possible to process certain geographic data effectively and to connect them with data and user attributes that are the subject of a research (Beconytè et al. 2010). This all together creates an excellent basis for effective evaluation and estimation of a certain area.

Starting with the fact that GIS is being continually expanded and improved, nowadays it can be applied in various fields which operate with spatial data and in decision making process realted to them (www.gis.com).

Geomarketing is a novelty in marketing field which allows optimization of the market via spatial analysis (Senić 2009). It facilitates starting a new or improving an already existing business. It implies using GIS with the aim of obtaining answers to numerous questions and requests from the field of marketing, sale and provision of services. Due to the fact that it combines geographic data with other kinds of information (names, classifications, addresses etc.), generating of various visual maps and reports is now possible. It is a system which often is not that easy to comprehend, because it can be seen on numerous levels and has different meanings to different people. For some, GIS is a software used for entering, storing, handling, analysis and display of spatial oriented data, while for the others it could be a philosophy, a way of decision making within an organization.

Experience and theory show that data are the most valuable part of GIS. In service providing systems, those data that can become a useful information are relevant and they can be spatially and geographically defined at the same time. It is possible to use both official data, such as, for example, census of population results, and internal data, for example number of requested services per individual customers, per categories etc., which can be georeferenced. The results of the applied technology are zoned presentations on the basis of which efficient analyses of customers, market and sale can be made, as well as answers obtained to numerous questions such as:

1. What is the spatial distribution of clients / customers / users?

2. What and where are the segments of.users with the greatest potential?

3. Are the post offices well located in relation to the distribution of users?

4. Which is the best location for a new sales oulet?

5. How many households are there in the area that gravitates towards the new location?

6. What is the purchasing power of these households?

7. Where is the competition located?

8. Where are the competition sales oulets located?

9. How is the market participation of the company and competition distributed?

10. What is the difference between the estimated potential and the achieved results of the sales staff?

11. Are the selected channels of delivery or courier service adequate for the efficient servicing of the market? 
The data about infrastructure, competition companies, nearness of business centres, age and class structure of the population, population density, current demand for certain sorts of services, i.e. all that can serve as a guideline for the observed business activity is entered on the map of the area whose potentials are to be examined.

For this type of marketing, it is most important to have a solid and updated database so that the results could be as reliable as possible. The result of a solid database are information about the type of business that could be successfully started there, or for the existing companies and services which type of marketing is most suitable in that area.

\section{The needs of postal service providers}

Competition in the field of universal services becomes more and more obvious in large urban areas. However, if we focus on commercial services, which imply all postal services except for the universal, including added value services, it is quite easy to notice that the competition usually appears on the express and courier service market (Bukumirović, Blagojević 2008). It is the type of services whose basic added value is door-to-door delivery. During the last few decades they developed into a separate industry. They equally include transport of documents, letters, packages and commercial goods.

There is no budgetary subsidy regulated by the state and, thus, there is no financial security in these areas. It is an extremely profitable market where everyone has to fight for their own share. In what way? The solution is often searched in segmentation as a certified means of market division which can boost company`s profitability (Grgurović, Braković 2004).

The postal service market is highly complex, with numerous customers having very heterogenous needs, wishes, motifs and models of behaviour (Grgurović, Milovanović-Braković 2003). It is almost impossible to satisfy the whole range of specific requirements. Therefore, the market segmentation process itself cannot be simple. That significantly complicates the process of selecting the target market and market strategy formulation (Filipović 1997). The ultimate goal of this process is gaining competition advantage, making customers permanantly loyal, by providing certain services which are customized to the requirements of a narrowly defined submarket (Aćimović 2003). The beginning of a segmentation process implies creating basic segment structure of a market. Using of a current structure is justified by the fact that the volume of business allows certain averaging. At some of the following steps, on the basis of new groups of users, there can even occur a possibility of reorganisation of a whole company which would require certain mergings (Grgurović, Štrbac 2008).

\section{The application of GIS in postal traffic}

With the development of GIS, i.e. creation of a sufficient number of vector maps to which large quantities of important data can be attached, the conditions for application of the technology in postal traffic and in the area of postal market segmentation have been fulfilled. The coming requirements, which postal service providers have to face and reply to.in an adequate way, are quite diverse and increasingly complex (Marković, Grgurović 2005). Market liberalization and flow of various sorts of parcels also dictate different approach to market 
segmentation. Over the period of last few years a significant change occured in customers ' requirements concerning the number and quality of transport of packages, post-express and direct mail parcels.

All that, along with the fact that Public Enterprise of PTT Communications "Serbia" has had problems with reduced resources in large cities and over dimensioned capacities in rural areas, indicates that segmentation is an issue that should be seriously considered. The task of GIS is to connect databases with pre-formed vector maps and thus allow a completely different view of postal service market segmentation.

In Public Enterprise of PTT Communications "Serbia”, MapInfo software package is used for working with geographic information systems (Kokot 2006). The main precondition for creating valid and useful vector maps is a good and detailed basis. As the creation basis, there can be used a detailed topographic map or ortho-photo image in the scale not less than 1:3000 for urban cores and not less than 1:25000 for rural areas and roads between settlements. As an example in this paper, data related to an urban area were used.

The scale of 1:3000 for urban cores provides recognition of objects, especially with orthophoto images, which is necessary for a project engineer to mark them correctly. The first thing that should be taken into consideration when using ortho-photo images for creating a vector map is the year of the recording. If it is not that recent, some new buildings or even entire streets could be omitted. Such omissions could lead to wrong conclusions in case of market segmentation, especially if some business facilities with high concentration of legal entities are omitted, and, consequently, to making bad business moves and results.

The following step is geopositioning of a map or image. It is necessary to position the map in geographic scale that is compatible with other vector maps we use. In the postal administration of Serbia, Gauss-Krüger scale is used for formation of vector maps. In this process it is important that each newly created map be precisely positioned within a certain scale.

In Fig. 2, an ortho-photo image has been used as the basis for urban core and according to it a street network is charted (the process of street network and facilities charting itself as well as the code assigning procedure is not the subject of this paper). The following step is matching the data we possess with the assigned codes. Microsoft Office Access, which is compatible with MapInfo software, is used for attaching the data from a base. A precisely coded vector map is ready for entering almost infinite data quantities.

In postal traffic, a large number of various user categories can be noticed. Users from different areas usually have different requirements concerning the services that would satisfy their defined needs and identified discontents expressed through their wishes. The division suitable for this branch of traffic, or this service industry, which is primarily based on the extent of accomplished services (Mijatović 2003), is the one by which all users are divided into physical persons and legal entities, i.e. consumer market (services used for own consumption) and organisational market (services used for the purposes of production or normal operating of certain institutions).

In literature that deals with this subject matter, the general opinion is that application of some standard methods of demographic and psychographic segmentation (Kotler et al. 2002). facilitates the creation of a preliminary list of 'who buys'. Such approch itself does not define market rules and problems, a need for a particular service or unique advertising.measures that should be implemented, but it helps to determine the steps to be taken for different seg- 


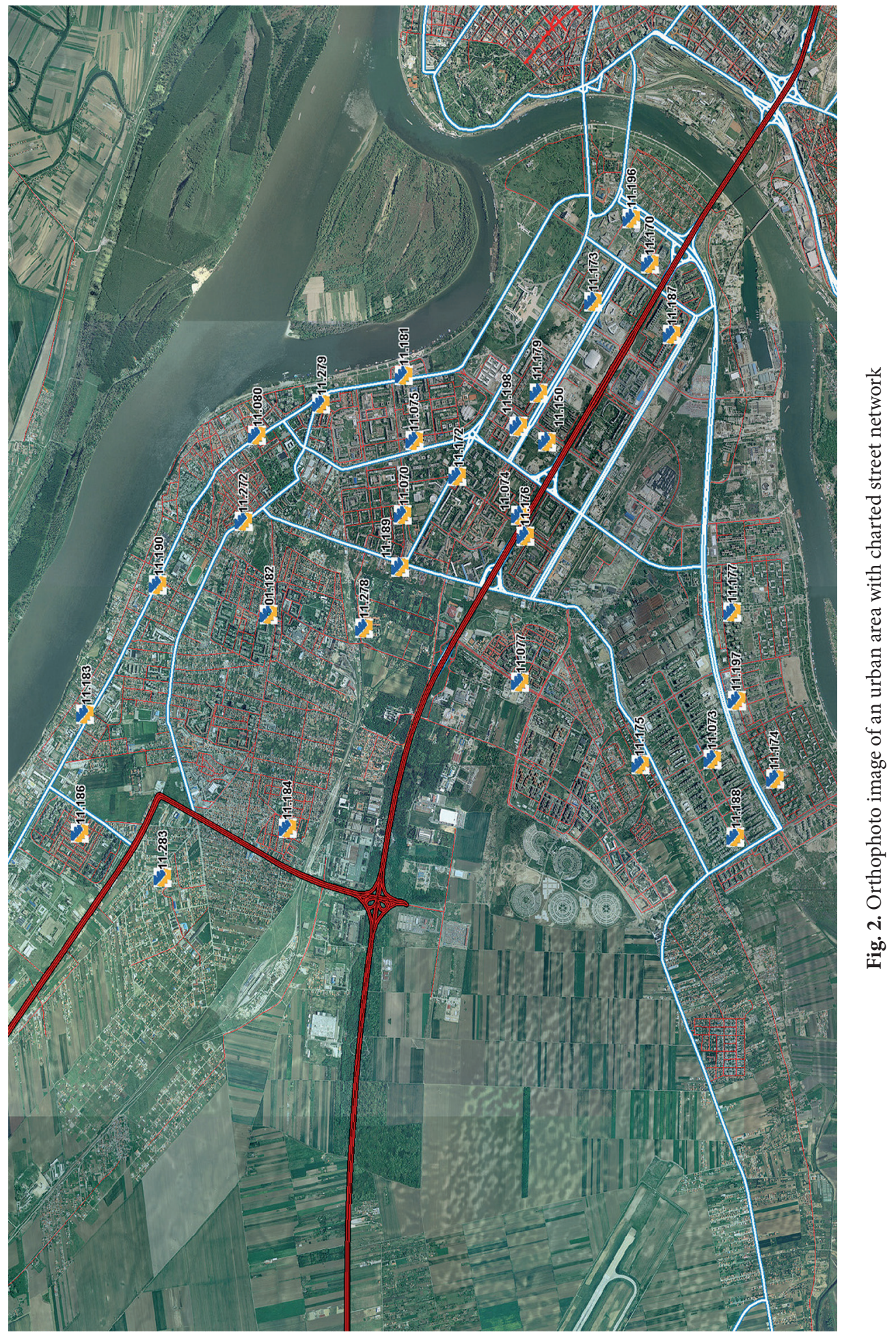


ments (Nelson 2003). The role of geographical criterion, in relation to other criteria that are applied in the process of segmentation, in the case of postal services may be the largest since it leads to data where the highest concentration of actual and potential users is.

By using the options that allow the creation of thematic maps via GIS (Janićijević 2007) we can quickly obtain information on the state in a certain area by this criterion (Figs 3 and 4).

Thematic map contains all essential information related to an area, such as data on the number of inhabitants, companies and their activities, the extent of committed services, address codes for each part of the settlement, etc. Information necessary for the creation of thematic maps can be obtained by connecting to the application "Territory". This application could be updated from time to time or daily by employees of some working units of the company. This would provide for the data entered in vector maps to be fresh and accurate.

On the basis of available data, it is possible to divide an area by certain criteria to the adequate number of segments (Grgurović, Štrbac 2006). The division criterion based on the extent of demand of a particular postal traffic service, provides, beside the usual division into two already mentioned groups, an additional division into the following customer groups:

a) Physical persons,

b) Legal entities - large users,

c) Legal entities - a small volume of service demand and

d) Legal entities who are not beneficiaries of Public Enterprise of PTT Communications "Serbia".

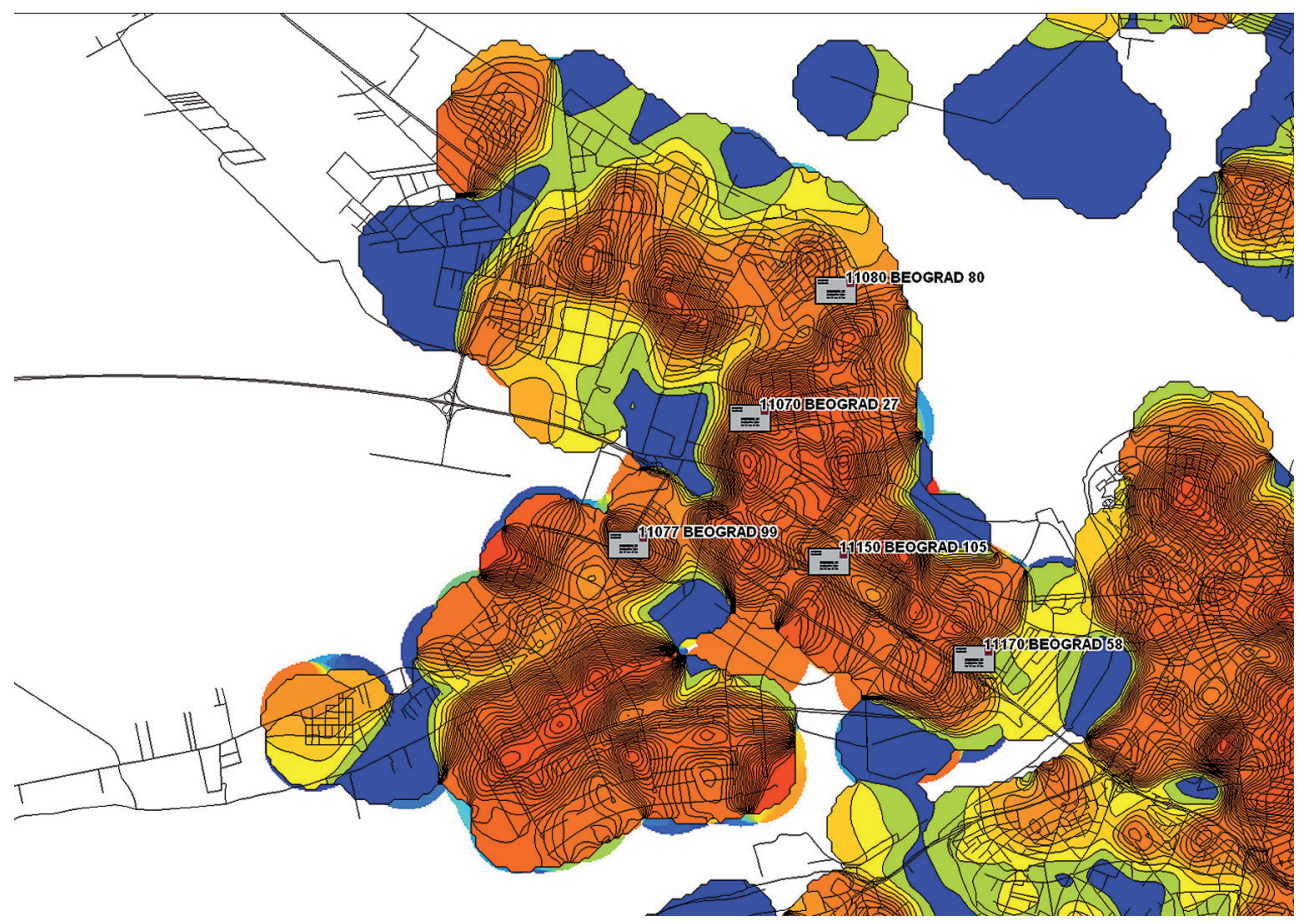

Fig. 3. Population density in an urban area 


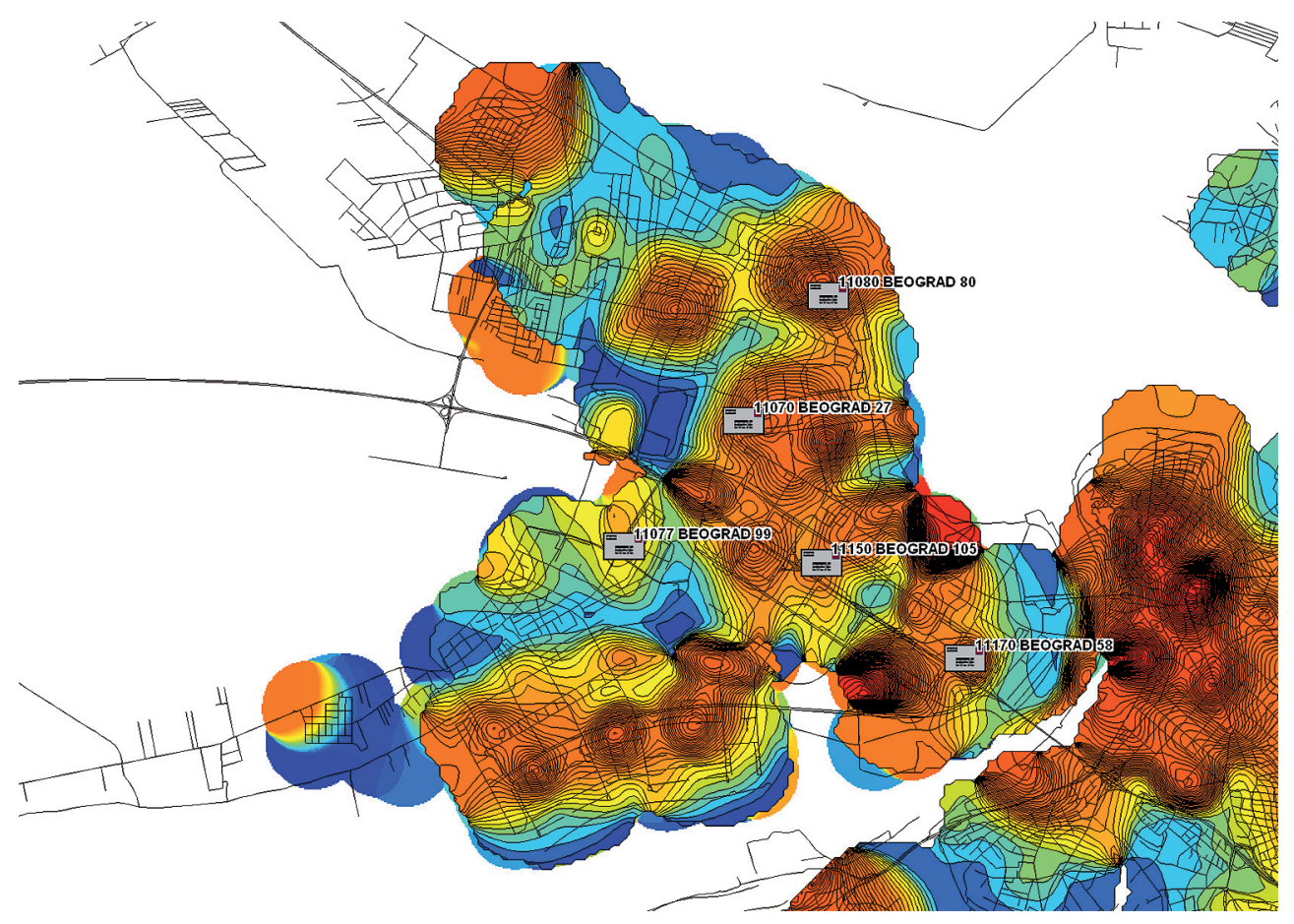

Fig. 4. Legal entities density in an urban area

In this section, it is possible to form another group for potential users of the observed market whose potential needs have been perceived anyhow.

\section{GIS - segmentation on the example of postexpress service}

Introduction of new services and changes in the volume of demand of the existing ones results in adaptation of organization to these challenges (O'Loughlin, Coenders 2002). As it is well known, the post express service means different initial-final operations and, thus, special organization of technology-traffic means and personnel, for better customer service (Sage 2001).

On the basis of demand density images for certain types of parcels, it is possible to reach certain conclusions. A series of conventional plans, which contain only certain selected data (in this case, route and unit network of the postal network), is overlapped and thus a plan was created (Nedeljković, Zagorac 2006).

As can be seen in Fig. 5, which shows the position of legal entities who demand post express (black dots) in relation to the position of postal network units for the provision of services to customers who receive these parcels, with the density given according to the number of demanded services of this kind in the observed urban area, it is obvious that the requests for post express service usually appear in certain "business" zones. 


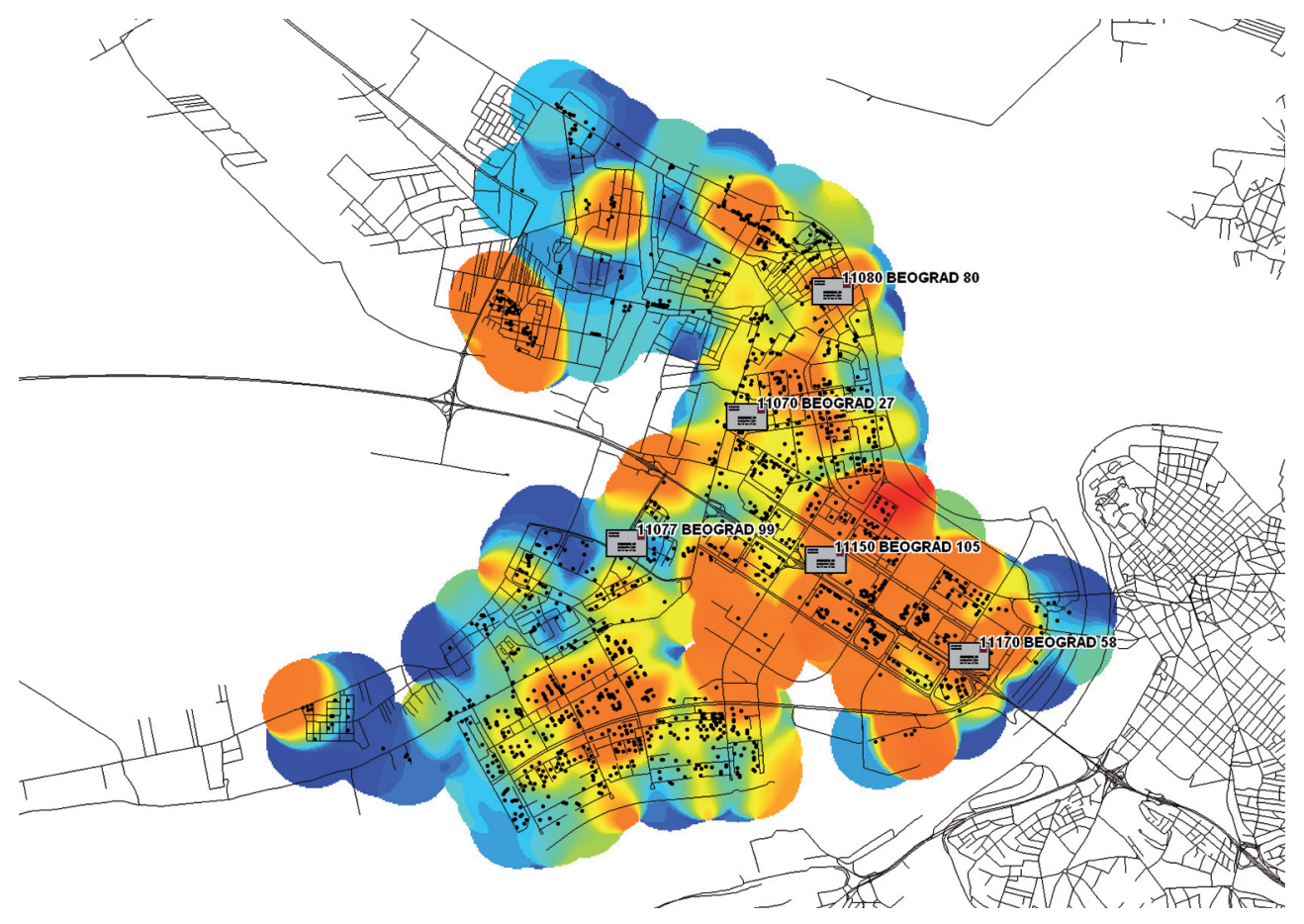

Fig. 5. Position of legal entities with densities given in relation to the number of demanded services in an urban area

Colours ranging from blue through green, yellow and red represent densities in percentages of $25 \%$. Compared to Fig. 4, one can immediately notice the difference and determine which part of this market consists of legal entities that are not the users of post-express services of Public Enterprise of PTT Communications "Serbia” (fourth defined user group).

Using the data that define them, it is possible to get another picture that would represent the status of those legal entities. Such representation could open up numerous advantages, starting from those related to the ability of identification of unsatisfied needs of that particular group. Through a detailed analysis of possible events in case of attraction of these legal entities by defining a differential advantage as a feature of this service, an opportunity for creating a new segment would be made.

As already said, the legal entities - users, starting from the scope of required services, can be divided into two basic groups. A detailed economic analysis of cost-effectiveness of providing post-express services, would allow the Post to make a cross-section and reach the conclusions about the cost-effectiveness of their business activities, where potential savings could be made and what segment special attention should be paid to (Nedeljković 2005).

On the basis of data from the database a decision about the size of the segment is made by connecting territories on which certain users are located in an integral entity. That way, it would be possible to define special courier teams and means of transportation for servicing the segment of legal entities - large users (Božić 1996). 
The existing data on the demand by physical entities show that they rarely opt for a demand via courier. However, if this group of users would be connected with the legal entities who demand a smaller scope of services, another field of operation might be opened for Public Enterprise of PTT Communications "Serbia”.

The great advantage of GIS is that it is able, on a daily level, to create a new organizational scheme, which directly leads to cost savings and increase of service quality, because it always operates with the optimal number of workers and vehicles. Such a direct organization of work with users will be possible in recent future. The databases are relatively easy to update, so that, with small investments and training of staff to work in GIS, significant savings could be made and, at the same time, a ready answer to the possible increase in the volume of services could be provided.

Collecting data on all relevant parameters for an observed area, such as population, number of households, number of legal entities with names and activities, amount of parcels sorted by types, frequency of demand (daily, occasionally, rarely, only in an emergency), data that indicate whether it is individual or group demands, payment methods, time of demand (Maričić 2002), number and location of service units... are the inexhaustible source of continuous and more effective market segmentation.

\section{Conclusion}

Postal market is not homogeneous. There are some significant differences in the structure of clients. Taking into account specific features of postal market in the process of segmentation it is necessary to apply several crucially different criteria in order to define all types of clients and categorize their needs. In this way it is possible to conduct the research that should optimize relation between the supply and demand (Greenland et al. 2002) of this service. During last years, speed of response becomes a critical factor of competitiveness. Organizations having a high rate of tracking the changes can count on greater market share and long term profitability (Draker 2005).

The presented concept is based on one of the specificities of the postal traffic related to spatial data. Technological progress in this area creates a background for new possibilities, dynamic development and business flexibility. Application of geographic information system (GIS) enabled the development and use of new methods in the analysis of spatial data, which contributes to faster high-quality decision-making. Application of GIS provides the connection between the test ranges and the databases of population and legal entities that belong to the test range. This technology has enabled accomplishing analyses by different criteria.

If Public Enterprise of PTT Communications "Serbia" would like to respond to the challenge of the growing competition and remain the leader in their field of business, they need to accelerate the introduction of GIS in all parts of their business activities that are based on spatial data (JP PTT saobraćaja "Srbija" 2007), including the area of market segmentation. Subsequent joining of information obtained by the application of the geographic criterion with the information related to demographic and psychographic data (gender, age structure, lifestyle...) may contribute to the quality of a segmentation project. 
Effective and efficient business activity requires certain flexibility under specific conditions. Variable segments, as the opposite to the strictly defined segmental structure of the market which has numerous disadvantages, can be formed more frequently, even daily, on the basis of the number of set requests for accomplishing a service. Owing to the results obtained by the application of GIS, for a previous period as well as for the present, it is possible to define the priorities, foresee future events, provide fast reaction and avoid incidental situations which are the consequences of improperly implemented segmentation.

The suggested method is an attractive alternative to the traditional process of segmentation which usually proposes only one solution for a certain period of time, which, in case of greater changes in business conditions, may result in occurence of loss or unused potentials. Such approach allows an entirely new perspective of data analysis in the field of segmentation of the specific services market. The model is completely open to the broad area of application of this that each situation needed to define appropriate performance. The analysis is accomplished faster, better and less expensive and the results are instantly visible.

\section{References}

Aćimović, S. 2003. Servis potrošača [Customer Service]. Ekonomski fakultet Univerziteta u Beogradu. Beograd, Srbija.

Ascher, B. 2002. Classification of Express Delivery Services, 2002. Universal Postal Union, Council of Administration Project Team on WTO Relations Berne, Switzerland.

Beconyte, G.; Kryžanauskas, A. 2010. Geographic communication for sustainable decisions, Technological and Economic Development of Economy 16(4): 603-612. doi:10.3846/tede.2010.37

Berry, L. L.; Wall, E. A.; Carbone, L. P. 2006. Service Clues and Customer Assessment of the Service Experience: Lessons from Marketing, Academy of Management Perspectives 20(2): 43-57.

Božić, V. 1996. Upravljanje fizičkom distribucijom [Management of Physical Distribution]. Ekonomski fakultet Univerziteta u Beogradu. Beograd, Srbija.

Bukumirović, M.; Blagojević, M. 2008. Kurirska, ekspres i paketska služba i sledljivost pošiljaka u poštanskoj logistici [Courier, express and parcel service and folowness of items in postal logistic], in PosTel 2008, XXVI simpozijum o novim tehnologijama u poštanskom i telekomunikacionom saobraćaju, Saobraćajni fakultet, Beograd, Srbija, 157-166.

Cuadra, R.; Ronderos, G. 2004. Guide to postal reform and development. Development Cooperation Directorate International Bureau Universal Postal Union. Berne, Switzerland.

Directive 97/67/EC - Comon Rules for the Development of Internal Market for Community and the Postal.

Draker, P. 2005. Upravljanje u novom društvu [Management in the New Society]. Adižes, Novi Sad.

Filipović, V. 1997. Marketing i tržište [Marketing and Market]. Fakultet organizacionih nauka Univerziteta u Begradu, Beograd, Srbija.

Greenland, S.; Coshall, J.; Combe, I. 2002. Evaluating Service Quality \& Customer Satisfaction in Emerging Markets, International Journal of Consumer Studies 30(6): 582-590. doi:10.1111/j.14706431.2005.00484.x

Grgurović, B.; Marković, D. 2005. Poštanske usluge i mreža [Postal Services and Networks]. Visoka škola strukovnih studija za informacione i komunikacione tehnologije, Beograd, Srbija.

Grgurović, B.; Milovanović-Braković, G. 2004. Segmentacija tržišta [Market Segmentation], in PostFest 2004, Zlatibor, Srbija.

Grgurović, B.; Milovanović-Braković, G. 2003. Istraživanje ponašanja korisnika poštanskih usluga [Research User Behavior Postal Services], in DQM-2003 Dependability and Quality Management, Beograd, 764-770. 
Grgurović, B.; Štrbac, S. 2006. Segmentacija poštanskog tržišta [Segmentation of the Postal Market], in PosTel 2006, XXIV simpozijum o novim tehnologijama u poštanskom i telekomunikacionom saobraćaju, Saobraćajni fakultet, Beograd, Srbija.

Grgurović, B.; Štrbac, S. 2007. Procedura izrade tržišne mape [Procedure of Market Map Creation], in PosTel 2007, XXV simpozijum o novim tehnologijama u poštanskom i telekomunikacionom saobraćaju, Saobraćajni fakultet, Beograd, Srbija.

Grgurović, B.; Štrbac, S. 2008. Formiranje preliminarnog spiska korisnika poštanskih usluga [Formation of the Preliminary List of Postal Service Users], in PosTel 2008, XXVI simpozijum o novim tehnologijama u poštanskom i telekomunikacionom saobraćaju, Saobraćajni fakultet, Beograd, Srbija, 177-186.

Janićijević, P. 2007. ICT u kurirskim službama - GIS i CAD tehnike [ICT in courier services - GIS and CAD tecniques], Stručno informativni časopis za poštansku industriju Savremena pošta (2): 89-96. Beograd.

JP PTT saobraćaja „Srbija“, 2008. Direkcija za poštanske usluge. Istraživanje tržišta, organizacije pružanja i cena paketskih i ekspres usluga [Market Research, Organization and Cost of Parcel Post and Express Service]. Beograd, Srbija.

JP PTT saobraćaja „Srbija“, 2007. Strateški plan JP PTT saobraćaja „Srbija“za period 2008-2010 [Strategic Plan Public Enterprise of PTT Communications "Serbia” for the period 2008-2010]. Beograd, Srbija.

Kokot, M. 2006. Osnove GIS tehnologije [Basics of GIS Technology], Stručno informativni časopis za poštansku industriju Savremena pošta, Beograd (2): 62-67.

Kotler, P.; Jain, D. C.; Maesincee, S. 2002. Marketing Moves. Boston: Harvard Business School Press.

Lijn, N.; Meijer, A.; Bas, P.; Volkerink, B. 2005. Development of competition in the European postal sector. MARKT/2004/03/C, Rotterdam.

Maričić, B. 2002. Ponašanje potrošača [Behavior Consumer]. Savremena administracija, Beograd, Srbija.

Marković, D.; Grgurović, B. 2006. Poštanski saobraćaj [Postal Service]. Saobraćajni fakultet Univerziteta u Beogradu, Beograd, Srbija.

Marković, D.; Grgurović, B. 2005. Mogući pristupi segmentaciji tržišta [Possible approaches to market segmentation], in XXIII simpozijum o novim tehnologijama u poštanskom i telekomunikacionom saobraćaju, Saobraćajni fakultet, Beograd, Srbija.

McDonald, M.; Dunbar, I. 2004. Market Segmentation. Elsevier Butterworth - Heinemann, Oxford.

Mijatović, Lj. 2003. Segmentacija tržišta u sistemu marketing odlučivanja [Market segmentation in the marketing decision-making], in DQM-2003 Dependability and Quality Management, Beograd, 782-785.

Narodna skupština Republike Srbije. 2005. Zakon o poštanskim uslugama [Postal Services Law], Službeni glasnik RS (18): 15-23. Beograd.

Nedeljković, S.; Zagorac, Đ. 2006. Implementacija poštanskog adresnog koda u GIS 'upravljanje teritorijom' [Implementation of post adress code in GIS 'territory management'], Stručno informativni časopis za poštansku industriju Savremena pošta (2): 68-72. Beograd.

Nedeljković, S. 2005. Primena GIS-a u organizaciji dostave [Application of GIS in Delivery Organisation], Stručno informativni časopis za poštansku industriju Savremena pošta (3): 55-60. Beograd.

Nelson, C. 2003. Geodemographic Segmentation: Do Birds of a Feather Flock Together?. Available from Internet: <http://www.foreseechange.com/Geodemographic\%20Segmentation.pdf>.

O'Loughlin, C.; Coenders, G. 2002. Application of the European Customer Satisfaction Index to Postal Services. Structural Equation Models versus Partial Least Squares. Department d'Economia, Universitat de Girona, Girona, Sage, D. 2001. Express Delivery. Handbook of Logistics and Supply-Chain Management, Hamburg.

Senić, V. 2009. Geomarketing: optimizacija tržišta putem prostorne analize [Geomarketing: Optimization of the Market through the Spatial Analysis]. Izazovi marketinga u kriznim vremenima, Ekonomski fakultet u Kragujevcu, Kragujevac. 


\section{GEOINFORMACINIŲ DUOMENŲ NAUDOJIMAS PAŠTO PASLAUGŲ RINKAI SEGMENTUOTI}

\section{Marković, B. Grgurović, S. Štrbac}

Santrauka. Dèl šiuolaikinių tendencijų pašto paslaugų teikejų pasaulyje nuolat daugejja. Todèl rinkoje ịsitvirtino griežti reikalavimai pašto paslaugų struktūrai ir kokybei. Kita vertus, vartotojai yra nevienalytė grupé, turinti skirtingų poreikių. Tai labai komplikuoja rinkos segmentaciją ir adekvačios rinkodaros strategijos suformulavimą. Autorių nuomone, kai kurių standartinių demografinių ir psichografinių segmentacijos metodų taikymas sudaro galimybes atlikti bendrą, dažnai prielaidomis paremtą grupavimą. Siekiama atkreipti dèmesị i geoinformacinių duomenų svarbą ir duomenų naudojimą pašto paslaugų rinkai segmentuoti.

Reikšminiai žodžiai: pašto siuntos, rinka, segmentavimas, vartotojai, pašto paslaugos, erdviniai duomenys, geografinès informacijos sistema (GIS).

Dejan MARKOVIĆ. Associate Professor at the Faculty of Transport and Traffic Engineering, University of Belgrade. Besides M. Sc. Thesis and Doctoral Thesis, he published the following works as either the author or co-author: 1 monograph, 2 course books, 1 paper in an international magazine, 14 papers in home magazines, 7 papers at international conferences and 35 at home conferences. He supervised the carrying out of 8 scientific-research projects, among which 3 projects are international, he was a consulting editor of 3 course books and he is an official consulting editor in the 'Contemporary Post Office' magazine.

Biljana GRGUROVIĆ. A senior lecturer at the Higher Education School of Professional Studies for Information and Communication Technologies. She defended a Master thesis on the topic "The use of marketing concept for the increase of postal traffic effectiveness" at the Faculty of Traffic and Transport Engineering in Belgrade, Serbia. Currently working on a Doctoral thesis on the topic "Market segmentation in function of development of postal traffic services" at the same faculty. Besides M. Sc. Thesis, she published the following works as either the author or co-author: one monograph, 4 course books, 7 papers in home magazines, 6 papers at international conferences and 22 at home conferences. She is an official consulting editor in the 'Contemporary Post Office' magazine. Research area: postal trsaffic, service industry market.

Slavica ŠTRBAC. Teacher of Practical Training at the Higher Education School of Professional Studies for Information and Communication Technologies. She graduated from the Faculty of Transport and Traffic Engineering, University of Belgrade and, at present, she is a postgraduate student of specialist studies at the Faculty of Organizational Studies, Department of E-Business. She published the following works as either the author or co-author: 1 course book, 1 papers in home magazines, 4 papers at international conferences and 4 at home conferences. 